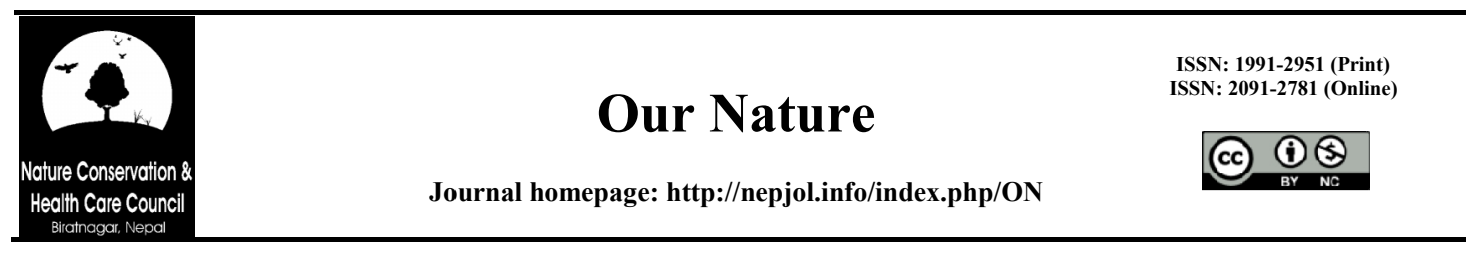

\title{
Note on taxonomy of Chlorogloeopsis fritschii (Mitra) Mitra et Pandey with soil analysis, collected from a rice field in West Bengal, India
}

\author{
Nilu Halder \\ Department of Botany, Raja Peary Mohan College, Uttarpara-712258, Hooghly, W.B., India \\ E-mail: niluhalder75@gmail.com
}

\begin{abstract}
While studying on paddy field blue green algae, author for the first time recorded a blue green algal species Chlorogloeopsis fritschii (Mitra) Mitra et Pandey from rice field soil in summer during 2013 in Hooghly, West Bengal, India. In the present paper, taxonomical description with microphotographs of the species has been provided. In addition to that, soil which was collected from the algal occurrence site has been analyzed. The different physico-chemical parameters of soil were as followed: $\mathrm{pH}$ : 7.1; EC: $0.142 \mathrm{dSm}^{-1}$; OC: 6.6 mgkg ${ }^{-1} ; \mathrm{Ca}^{2+}: 4.6 \mathrm{cmol}^{+} \mathrm{kg}^{-1} ; \mathrm{Na}^{+}: 0.71 \mathrm{cmol}^{+} \mathrm{kg}^{-1} ; \mathrm{K}^{+}: 0.15 \mathrm{cmol}^{+} \mathrm{kg}^{-1} ; \mathrm{CEC}: 12.6 \mathrm{cmol}^{+} \mathrm{kg}^{-}$ 1, WHC: $45 \%$. Soil textures were as: sand: $36.2 \%$, slit: $28.1 \%$ and clay: $35.7 \%$. This study of soil showed its nature and present nutrient content. As the alga contains heterocyst and can fix atmospheric nitrogen to soil so, it can apply in rice fields as biofertilizer to enhance the yield of rice and increase of soil fertility.
\end{abstract}

Key words: Green algae, Hooghly, Physico-chemical parameters, Rice field

DOI: http://dx.doi.org/10.3126/on.v14i1.16445

Manuscript details: Received: 23.01.2016 / Accepted: 18.04.2016

Citation: Halder, N. 2016. Note on taxonomy of Chlorogloeopsis fritschii (Mitra) Mitra et Pandey with soil analysis, collected from a rice field in West Bengal, India .Our Nature 14(1): 92-98. DOI: http://dx.doi.org/10.3126/on.v14i1. 16445

Copyright: (C) Halder 2016. Creative Commons Attribution-NonCommercial 4.0 International License.

\section{Introduction}

Cyanobacteria are an ancient group of photosynthetic prokaryotes (Seal et al., 2014) and Gram negative bacteria (Seal et al., 2015) that exist continuously since the early evolution of biosphere in the earth (Barghoorn, 1992; Řezanka et al., 2003) and are able to grow in diverse habitats (Halder and Sinha, 2013a, b). 
The members of Nostocaceae are trichomatous, mucilaginous, odoriferous, bluish-green, with or without sheath, heterocystous or non-heterocystous, unbranched. Ttropical hot, dry and, humid conditions help their luxuriant growth in various ecosystems (Halder, 2015). Chlorogloeopsis fritschii (Mitra) Mitra et Pandey is a filamentous heterocystous cyanobacterium and shows variations in morphology and diversities of functions. It can also tolerate varieties of climatic conditions required for growth and survival (Evans et al., 1976) like that of other blue green algal species (Halder and Sinha, 2013a). This blue-green alga can fix atmospheric nitrogen to a limited extent in soil (Fay, 1965) and nitrogen-fixing activity is found greatest during exponential growth in smallcelled filaments that developed from the endospores (Fay et al., 1964). Nitrogenase activity in the heterocyst of this species under aerobic condition was documented earlier (Kenyon et al., 1972). Besides these, the alga is very important regarding synthesis of photo-pigmentations and few biochemical products. It has been recognized that chlorophyll (chl.) a along with chl. $\mathrm{b}$ and $\mathrm{c}$, phycobilins, and caroteinoids contribute to oxygenic photosynthesis by harvesting the light energy (Grossman et al., 1995). Study of scientific literature showed that the alga produced chl $\mathrm{f}$ and chl $\mathrm{d}$ pigments when cultured under natural and near-infrared (IR) lights in a column photobioreactor (Airs et al., 2014). Chlorophylls $\mathrm{f}$ and $\mathrm{d}$ are red-light inducible chlorophylls and play significant role as an accessory pigments in far-red type of oxygenic photosynthesis by absorbing red light. Chlorophyll $\mathrm{f}$ is the most recently discovered longest wavelength absorbing chlorophyll, although its structure and biophysical prop- erties are resolved, and has only been reported from this cyanobacterial strain in wet environments (Behrendt et al., 2015). Chemical analysis of fatty acid composition of this species exhibited low content of poly-unsaturated (mono and tri) fatty acids (Kenyon, 1972). The occurrence of poly- $\beta$ hydroxybutyrate (PHB) in this blue-green alga was reported earlier (Carr, 1966). PHB is a polymer belonging to the polyester class that is used for biodegradation of plastics. The existence of the glyoxylate cycle, a variant of the TCA cycle, has been documented from the type Chlorogloeopsis fritschii PCC 9212 and the genes responsible for encoding isocitrate lyase and malate synthase enzymes are also identified. The glyoxylate cycle helps to coordinate carbon and nitrogen metabolism under condition of nitrogen fixation (Zhang and Bryant, 2015).

Soil is a valuable resource in our planet and one of the most significant ecological factors, on which plants dependent for their nutrients, water and mineral supply (Shaikh and Bhosle, 2013). The soil of Hooghly district, West Bengal in India is new alluvial type, most fertile and found along the Indo-Gangetic belt. As, it harbors the algal flora hence different parameters of the soil sample of the sampling site has been analyzed using the standard methods to find out soil profile characteristics and the relationships between algae and soil properties. As scanty information is available regarding physico-chemical parameters of soil and taxonomic work on this species therefore, the present study was undertaken.

\section{Materials and methods}

The Algal sample was collected in plastic and glass containers from a paddy field during puddling stage of rice from Balagarh $(\mathrm{N}$ $23^{\circ} 12^{\prime}$, E 88 $46^{\prime}$ ), in Hooghly, West Ben- 
gal, India. Microscopic examination was made under Olympus microscope (Model$\mathrm{CH} 20 \mathrm{i})$. Algal sample was preserved in $4 \%$ formalin solution and the voucher specimen was deposited in the Departmental Herbarium of the Department of Botany, Raja Peary Mohan College, Uttarpara, West Bengal. Identification of the taxa had been made following scientific literature viz. Mitra and Pandey (1966) and Guiry and Guiry (2015). For soil analysis, surface soil sample about 500 gm from a depth of $10 \mathrm{~cm}$ was collected, air dried, brought up in the laboratory, grounded and homogenized with a mortar and pestle and pass through a $2.0 \mathrm{~mm}$ sieve. Various physico-chemical parameters of soils were analyzed by different techniques. To obtain clear supernatant of soil sample centrifugation was done using a Remi centrifuge (model, R-23). The standard Munsell colour charts (Munsell colour Co., 1975) was used for identifying the colour of soil sample. The $\mathrm{pH}$ of the sample as soil suspension was recorded with the help of a pH meter (Jenway, 3510) in the ratio of soil: water $=1: 2.5(\mathrm{w} / \mathrm{v})$. Electrical conductivity (EC) value of soil suspension (soil: water $=1: 2.5$ ) was measured at room temperature by a direct reading conductivity meter (Systronic, 303). The organic carbon (OC) content of the soil sample was determined as procedure of Walkey and Black (1934) and outlined by Jackson $(1967,1973)$ while calcium $\left(\mathrm{Ca}^{2+}\right)$ was determined by EDTA titration method (Chapman, 1965). Sodium $\left(\mathrm{Na}^{+}\right)$and potassium $\left(\mathrm{K}^{+}\right)$cations were determined with the help of a flame photometer (Systronic, 121). Water holding capacity (WHC) was determined by Keen box method following Piper (1966). Soil texture (particles size distribution) as percentages of sand, silt and clay fractions was determined by the hy- drometer method adapted by Bouyoucos (1962). All the statistical analyses were done using the statistical package for social sciences (SPSS v. 13, Inc., USA).

\section{Results and discussion}

Morpho-taxonomic description of Chlorogloeopsis fritschii (Mitra) Mitra et Pandey under light microscopy had been provided here. The alga was collected in the month of March during summer from a paddy field in a locality of Hooghly district, West Bengal, India. Systematic position of the species was mentioned according to Mitra and Pandey (1966).

Phylum- Cyanophyta; Class- Cyanophyceae; Family- Chlorogloeopsidaceae; Order- Stigonematales; Genus- Chlorogloeopsis A.K. Mitra et D.C. Pandey (1967)

Chlorogloeopsis fritschii (Mitra) Mitra et Pandey in Phykos 5(1-2): 111-113, figs.129, 30-40, 41-54, 1966 (Figs. A-C)

Chlorogloea fritschii Mitra (1950)

Description: Thallus blue-green, forms a crust or compact stratum of indefinite size and composed of rounded or irregular cell packets; cells arranged in vertical and horizontal rows, rounded or angular without any distinct mucilaginous sheath with pale blue-green granular contents; usually 6.0 $8.0 \mu \mathrm{m}$ in diameter; reproduction takes place by separation of single cell or cells in groups of two or more; heterocysts terminal and intercalary; $2.0-4.5 \mu \mathrm{m}$ broad and 2.0$4.0 \mu \mathrm{m}$ long and irregularly disposed; endospores naked, spherical, 4.0-9.0 $\mu \mathrm{m}$ in diameter, formed singly or more (upto four) within the cells and released by the rupture of mother wall; germination of endospore forms uniseriate filament of 3-16 (-20) cells which divides to produce cell packets. 
Habitat: The alga was grown in a rice field at Balagarh, Hooghly, West Bengal, India Date of collection: 18.03.13; Collection number: NH-1260

Significance: The algal species is nitrogen fixer and increase soil fertility

It was Mitra (1950) who first time reported the occurrence of a blue-green algal species Chlorogloeopsis fritschii (Mitra) Mitra et Pandey with morphological description and illustrations from cultures of cultivated and uncultivated soils in Allahabad, Uttar Pradesh, India. Previously, he included it as a new species belonging to the family Entophysalidaceae under the order Chroococcales of Cyanophyta but later he found the development of heterocysts in this algal species that led the author to review the morphological features and finally documented it as new taxon in algal science and also changed its taxonomic status. He established it under a separate genus Chlorogloeopsis A.K. Mitra et D.C. Pandey of the family Chlorogloeopsidaceae belonging to the order Stigonematales of class Cyanophyceae. The present algal taxon exhibited vertical and horizontal divisions of cells and has a tendency to form filamentous structure. Besides these, some other characters like habitat, colour, measurements and organization of cells were alike with the type species. So, the morphological characteristics agreed with the previous reports by Mitra (1950) and Mitra and Pandey (1966) and the present study also confirmed the earlier taxonomical findings.

The physical and chemical properties of the soil from sampling site at Balagarh, Hooghly, West Bengal were presented in Table 1. The colour of soil was observed as yellowish-brown. Soil $\mathrm{pH}$ influences the richness and diversity of plant species by enhancing the solubility of nutrients as well as availability of nutrient to plant (Gough et al., 2000). In the present study, soil $\mathrm{pH}$ was found slightly alkaline. Electrical conductivity (EC) expressed ion contents of soil solution which determined the carrying capacity and thus, giving a clear idea of the soluble salts present in the soil (Addis and Abebaw, 2014). The mean value of EC at the sampling time was $0.142 \mathrm{dSm}^{-1}$. Organic carbon was measured as $6.6 \mathrm{mgkg}^{-1}$. The nutrient contents like $\mathrm{Ca}^{2+}, \mathrm{Na}^{+}$and $\mathrm{K}^{+}$ were noticed in appreciable amounts and they were found the most essential elements for the growth and development of this algal species. Cation exchange capacity (CEC) usually depends on the clay fractions and organic carbon/matter present in soil. This value was found to be $12.6 \mathrm{cmol}^{+} \mathrm{kg}$ ${ }^{1}$ which was good indication of fertile soil and nutrients retention capacity. Water holding capacity (WHC) is the amount of water that retains in the soil as soil moisture. It was measured as $45 \%$ in soil from the study site. The textural class was claysandy loamy at the top of soil. The result of particle size distributions of soil texture composed of different fractions. Sand$36.2 \%$, slit- $28.1 \%$ and clay- $35.7 \%$ were determined from soil analysis. On the basis of analysis of soil sample it can be concluded that soil is highly fertile and hence supports the occurrence and growth of algal flora.

\section{Conclusions}

In the young condition, the algal species consist of straight and short filament/s. Vegetative cells were found as singly, 2-celled and many celled or in groups but in older stage, the cells divided vertically and horizontally to form packets of cells and devel- 

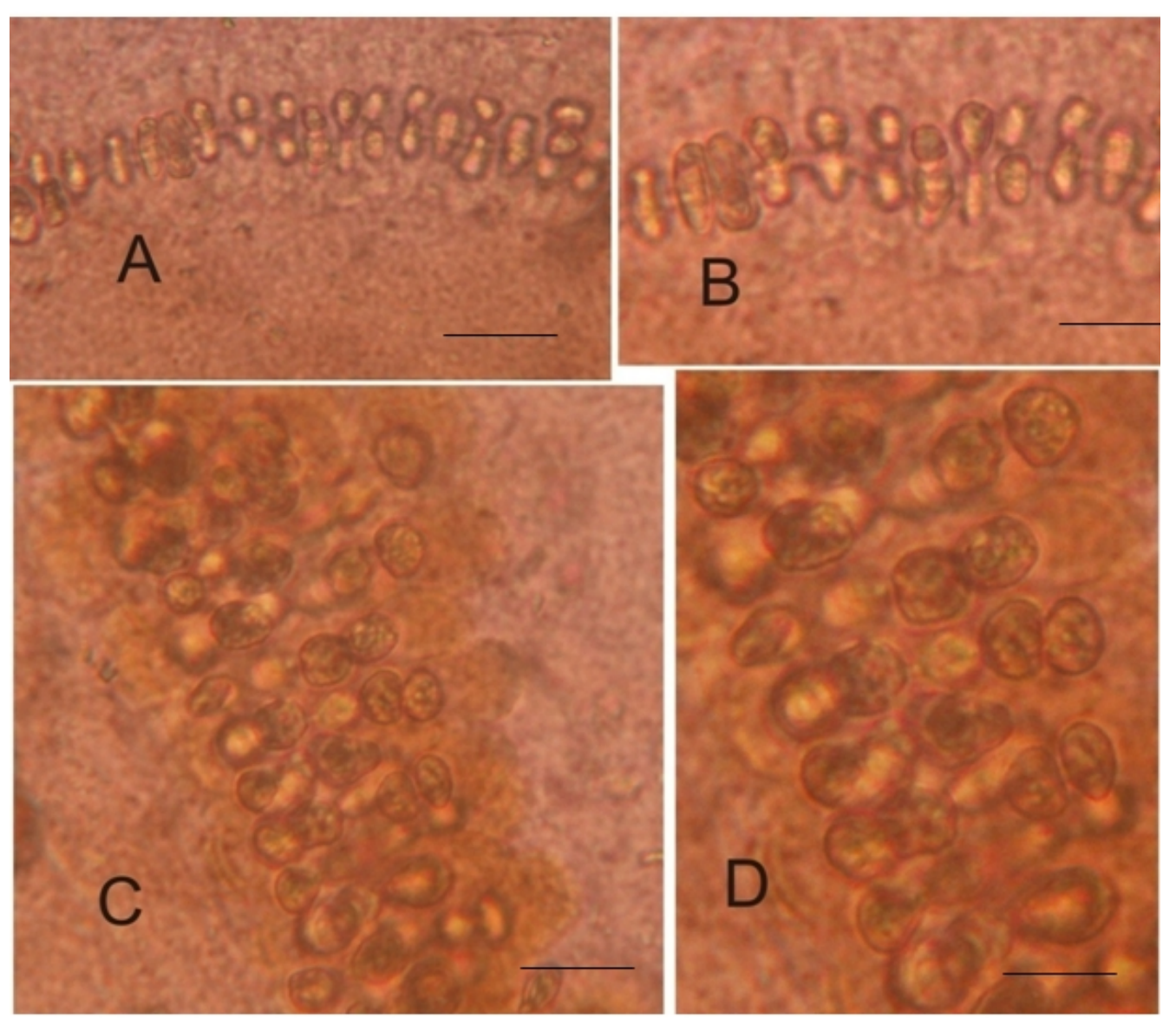

Figure 1A. Filament of Chlorogloeopsis fritschii showing vertical divisions, B. Magnified view of same filament, C. Many celled stage of the same species, D. Magnified view of fig. C. Scales $=30 \mu \mathrm{m}$

Table 1. Physico-chemical properties (Mean $\pm \mathrm{SE}$ ) of soil at the time of algal collection

\begin{tabular}{|c|c|c|c|c|c|c|c|c|c|c|}
\hline $\mathrm{pH}$ & $\mathrm{EC} \mathrm{dSm}^{-1}$ & $\begin{array}{c}\mathrm{OC} \\
\mathrm{mgkg}^{-1}\end{array}$ & $\begin{array}{c}\mathrm{Ca}^{2+} \\
\mathrm{cmol}^{+} \mathrm{kg}^{-1}\end{array}$ & $\begin{array}{c}\mathrm{Na}^{+} \\
\mathrm{cmol}^{+} \\
\mathrm{kg}^{-1}\end{array}$ & $\begin{array}{c}\mathrm{K}^{+} \\
\mathrm{cmol}^{+} \mathrm{kg}^{-1}\end{array}$ & $\begin{array}{c}\text { CEC } \\
\mathrm{cmol}^{+} \mathrm{kg}^{-1}\end{array}$ & $\begin{array}{l}\text { WHC } \\
(\%)\end{array}$ & $\begin{array}{l}\text { Sand } \\
(\%)\end{array}$ & $\begin{array}{l}\text { Slit } \\
(\%)\end{array}$ & $\begin{array}{l}\text { Clay } \\
(\%)\end{array}$ \\
\hline $.1 \pm 0.05$ & $0.142 \pm 0.1$ & $6.6 \pm 1.1$ & $4.6 \pm 1.7$ & $0.71 \pm 0.05$ & $0.15 \pm 0.2$ & $12.6 \pm 2.3$ & $45 \pm 0.28$ & $36.2 \pm 0.5$ & $28.1 \pm 0.4$ & $35.7 \pm 0.6$ \\
\hline
\end{tabular}

Each value was expressed with mean value \pm standard error of at least four replicates.

oped terminal heterocyst/s. The alga showed different successive stages of divisions during its growth to achieve uniseriate to multiseriate filaments and turned into blue greenish to pale yellowish colour at maturity. As the alga has nitrogen fixing efficiency due to presence of heterocysts in the thallus so, it could be used as biofertilizer at commercial scale to increase the fertility of habitats such as rice-fields. The soil study has been given some information about the nature of soil and present nutrient status of soil. 


\section{References}

Addis, W. and A. Abebaw 2014. Analysis of selected physicochemical parameters of soils used for cultivation of Garlic ( $A l$ lium sativum L.). Sci. Technol. Arts Res. J. 3(4): 29-35.

Airs, R.L., B. Temperton, C. Sambles, G. Farnharm, S.C. Skill and C.A. Llewellyn 2014 Chlorophyll $\mathrm{f}$ and chlorophyll $\mathrm{d}$ are produced in the cyanobacterium Chlorogloeopsis fritschii when cultured under natural light and near-infrared radiation. FEBS. Lett. 588(20): 3770-3777.

Barghoorn, E.S. 1992. The antiquity of life: In Environmental evolution (Margulis, L. and L. Olendzenski eds.). MIT Press, Cambridge (USA). pp. 71-84.

Behrendt, L., A. Brejnrod, M. Schliep, S.J. Sørensen, A.W. Larkum and M. Kühl 2015. Chlorophyll f-driven photosynthesis in a cavernous cyanobacterium. ISME. j. 9(9): 2108-21011.

Bouyoucos, G.J. 1962. Hydrometer method improved for making particle size analysis of soils. Agronomy J. 54: 464-465.

Carr, N.G. 1966. The occurrence of poly- $\beta$ hydroxybutyrate in the blue-green alga, Chlorogloea fritschii. Biochim. Biophys. Acta 120(2): 308-310.

Chapman, H.D. 1965. Cation exchange capacity. In Methods of soil analysis (Black, C.A., L.E. Ensminger and F.E. Clark eds.), Am. Soc. Agron., Inc, Madison, Wisconsin, USA. pp. 891-901.

Evans, H.E., I. Foulds and N.G. Carr 1976. Environmental conditions and morphological variation in the blue-green alga Chlorogloea fritschii. J. Gen. Microbiol. 92: 147-155.

Fay, P. 1965. Heterotrophy and nitrogen fixation in Chlorogloea fritschii. J. Gen. Microbiol. 39: 11-20.

Fay, P., H.D. Kumar and G.E. Fogg 1964. Cellular factors affecting nitrogen fixation in the blue-green alga Chlorogloea fritschii. J. Gen. Microbiol. 35: 351-360.
Gough, L., G.R. Shaver, J. Carroll, D.L. Royer and J.A. Laundre 2000. Vascular plant species richness in Alaskan arctic tundra: the importance of soil pH. J. Ecol. 88 : 54-66.

Grossman, A.R., D. Bhaya, K.E. Apt and D.M. Kehoe 1995. Light-harvesting complexes in oxygenic photosynthesis: diversity, control and evolution. Ann. Rev. Genet. 29: 231-288.

Guiry, M.D. and G.M. Guiry 2015. Algaebase. Worldwide electronic publication, $\mathrm{Na}$ tional University of Ireland, Galway (http://www.algaebase.org.).

Halder, N. 2015. New report of Anabaena Bory from Hooghly district in West Bengal, India. Int. J. Innovative Res. Rev. 3(1): 94-98.

Halder, N. and S.N. Sinha 2013a. Some new records of the species of the genera Aphanothece Näg and Merismopedia Meyen from Hooghly district, West Bengal, India. Indian J. Plant Sci. 2(3): 5865.

Halder, N. and S.N. Sinha 2013b. Diversity of the genera Gloeotrichia Agardh and Rivularia (Roth.) Agardh from Hooghly district of West Bengal, India. Indian $J$. Fundam. Appl. Life Sci. 3(3): 29-35.

Jackson, M.L. 1967. Soil chemical analysis. Prentice-Hall of Indian Pvt. Ltd., New Delhi. 498 p.

Jackson, M.L. 1973. Soil chemical analysis. Prentice Hall of India Pvt. Ltd., New Delhi. 205 p.

Kenyon, C.N. 1972. Fatty acid composition of unicellular strains of blue-green algae. $J$. Bacteriol. 109: 827-834.

Kenyon, C.N., R. Rippka and R.Y. Stanier 1972. Fatty acid composition and physiological properties of some filamentous blue-green algae. Arch. Microbiol. 83(3): 216-236.

Mitra, A.K. 1950. Two new algae from Indian soils. Ann. Bot. 14(4): 457-464.

Mitra, A.K. and D.C. Pandey 1966. On a new 
genus of the blue-green alga Chlorogloeopsis with remarks on the production of heterocysts in the alga. Phykos. 5: 106-114.

Piper, C.S. 1966. Soil and plant analysis. Hans Publishers, Bombay, India, pp. 223-237.

Řezanka, T., I. Dor, A. Prell and V.M. Dembitsky 2003. Fatty acid composition of six freshwater wild cyanobacterial species. Folia Microbiol. 48: 71-75.

Seal, T., N. Halder, K. Chaudhuri and S.N. Sinha 2014. Effect of solvent extraction system on the antioxidant activities of algae. Int. J. Pharm. Pharm. Sci. 6(10): 242245.

Seal, T., N. Halder, K. Chaudhuri and S.N. Sinha 2015. Evaluation of antioxidant activ- ities of algae and effect of solvent extraction system. IJPSR. 6(3): 1273-1278.

Shaikh, P.R. and A.B. Bhosle 2013. Heavy metal contamination in soils near Siddheshwar dam Maharashtra, India. Res. J. Chem. Sci. 3(1): 6-9.

Walkey, A. and I.A. Black 1934. An examination of Degtjareff method for determining soil organic matter and a proposed modification of the chromic acid titration method. Soil Sci. 37: 29-38.

Zhang, S. and D.A. Bryant 2015. Biochemical validation of the glyoxylate cycle in the cyanobacterium Chlorogloeopsis fritschii strain PCC 9212. J. Biol. Chem. 290(22): 14019-14030. 